\title{
A PROSPECTIVE STUDY TO ASSESS THE DIAGNOSTIC EFFICACY OF LABORATORY RISK INDICATOR FOR NECROTIZING FASCIITIS (LRINEC) SCORING SYSTEM IN PATIENTS WITH SOFT TISSUE INFECTION
}

Dr K. Vani

Professor \& HOD, GMC, GGH, Kadapa.

Dr Gattupalli

Bhaswanth Kumar

Reddy

Dr B. Jayakiran

Postgraduate, GMC, GGH, Kadapa.

Dr J. Ramanaiah*

Assistant Professor, GMC, GGH, Kadapa.

Dr. B. Balaji

Dr. Muntimadugu

Sharmila

Associate Professor, GMC, GGH, Kadapa. *Corresponding Author

Postgraduate, GMC, GGH, Kadapa.

Postgraduate, GMC, GGH, Kadapa.

\section{ABSTRACT Background}

Necrotizing fasciitis which is commonly known as "Flesh-Eating Disease" is an uncommon soft-tissue infection. It is characterized by widespread fascial necrosis with relative sparing of overlying skin and underlying muscle. Mostly it is associated with severe systemic toxicity and a fulminant course. It is usually rapidly fatal unless promptly recognized and aggressively treated with appropriate antimicrobials and surgical debridement at the earliest.

Methods

Our study was a prospective study conducted on 140 patients over a period of 2 years from June 2018 to June 2020 in a tertiary care hospital, GGH, Kadapa. All patients were selected randomly and evaluated by taking proper history, thorough clinical examination, routine laboratory investigations and histopathological examination of the debrided tissue and the outcomes were analysed to know the efficacy of LRINEC Scoring in diagonising necrotizing fasciitis.

Results

Most common age group was $41-50$ years. Males were commonly affected, accounting to $74 \%$ i.e., 111 patients and the remaining 39 patients were females (39\%). Fever, inflammation of the involved area were the most common presentations. Majority were diabetic and hypertensive accounting to $55.3 \%$ and $52.7 \%$ respectively. All patients presented with symptoms with swelling, redness, pain and induration. Eighty-one percent had elevated CRP. Total WBC count was raised in $78.7 \%$ of the cases. Fifty-six percent of the cases had haemoglobin less than $1 \mathrm{lg} / \mathrm{dl}$. Hyponatremia was observed in $81.3 \%$ of the patients. Majority (52.7\%) had normal sr. creatinine i.e., < or $=1.4$. RBS was elevated in $54.7 \%$ of the cases. In our study $87.3 \%$ of the patients had a LRINEC score $>6$. Histology was positive for necrotising fasciitis in $92 \%$ of the cases, among them majority had polymicrobial organisms on culture.

Conclusion

In patients with severe soft tissue infections, LRINEC scoring based on laboratory parameters is an easy and reliable diagnostic tool to diagnose Necrotizing fasciitis accurately.

\section{KEYWORDS : Necrotising fasciitis, LRINEC score, polymicrobial, monomicrobial.}

\section{BACKGROUND}

Necrotizing fasciitis which is commonly known as "FleshEating Disease" is an uncommon soft-tissue infection. It is characterized by widespread fascial necrosis with relative sparing of overlying skin and underlying muscle. Mostly it is associated with severe systemic toxicity and a fulminant course. It is usually rapidly fatal unless promptly recognized and aggressively treated with appropriate antimicrobials and surgical debridement at the earliest.

\section{METHODS}

Our study was a prospective study conducted on 140 patients over a period of 2 years from June 2018 to June 2020 in a tertiary care hospital, GGH, Kadapa. All patients were selected randomly and evaluated by taking proper history, thorough clinical examination, routine laboratory investigations and histopathological examination of debrided tissue and the outcomes were analysed to know the efficacy of LRINEC Scoring in diagonising necrotizing fasciitis.

The LRINEC (laboratory risk indicator for necrotizing fasciitis) ${ }^{1}$ score

LRINEC score of 6 or greater is considered positive for necrotizing fasciitis

\begin{tabular}{lc}
\hline Variable & Score \\
\hline C-reactive protein $(\mathrm{mg} / \mathrm{l})$ & \\
$\quad<150$ & 0 \\
150 or more & 4 \\
Total white cell count $\left(\right.$ per $\left.\mathrm{mm}^{3}\right)$ & \\
$\quad<15$ & 0 \\
$15-25$ & 1 \\
$>25$ & 2 \\
Hemoglobin $(\mathrm{g} / \mathrm{dl})$ & \\
$>13.5$ & 0 \\
$11-13.5$ & 1 \\
$<11$ & 2 \\
Sodium (mmol/l) & \\
135 or more & 0 \\
$<135$ & 2 \\
Creatinine $(\mu \mathrm{mol} / \mathrm{l})$ & \\
$\quad 141$ or less & 0 \\
$>41$ & 2 \\
Glucose (mmol/l) & \\
10 or less & 0 \\
$>10$ & 1 \\
\hline
\end{tabular}

Inclusion Criteria

Patients presenting with symptoms suggestive of severe soft 
tissue infections admitted from the emergency department or outpatient department between the age group 15-90 yrs residing in Kadapa area and surrounding villages who are willing to take part in this study are included in this study.

Exclusion Criteria

1) Patients below 15 yrs or above 90 yrs of age.

2) Patients who have received antibiotic treatment in the last 48 hours or a minimum of 3 doses of antibiotic prior to presentation.

3) Patient who has undergone surgical debridement for present episode of soft tissue infection.

\section{RESULTS}

Age Distribution:

Table 1 - Age Distribution Of Patients Studied

\begin{tabular}{|l|l|l|}
\hline Age in years & No. of patients & $\%$ \\
\hline $21-30$ & 2 & 1.3 \\
\hline $31-40$ & 18 & 12.0 \\
\hline $41-50$ & 55 & 36.7 \\
\hline $51-60$ & 43 & 28.7 \\
\hline $61-70$ & 22 & 14.7 \\
\hline $71-80$ & 8 & 5.3 \\
\hline $81-90$ & 2 & 1.3 \\
\hline Total & 150 & 100.0 \\
\hline
\end{tabular}

Mean \pm SD: $52.84 \pm 11.32$

Gender Distribution:

Males were commonly affected by necrotizing fasciitis accounting to $74 \%$ i.e., 111 patients the remaining 39 patients were females (39\%).

\section{Fever Status:}

Fever is present in all 150 patients (100\%).

\section{Diabetics:}

In our study, 83 patients were diabetic and 67 were nondiabetic accounting to $55.3 \%$ and $44.7 \%$ respectively.

\section{Hypertension:}

In our study, 79 patients were hypertensive and 71 were non hypertensive accounting to $52.7 \%$ and $47.3 \%$ respectively.

Chronic Kidney Disease And Peripheral Vascular Disease: In our study, 45 patients (30\%) had chronic kidney disease, and 2 patients $(1.33 \%)$ had PVD.

Table 2: Location Of Necrotizing Fasciitis

\begin{tabular}{|l|l|l|}
\hline Location & No. of patients & $\%$ \\
\hline Abdominal & 1 & 0.7 \\
\hline LL & 129 & 86.0 \\
\hline UL & 5 & 3.3 \\
\hline Scrotum & 15 & 10.0 \\
\hline Total & 150 & 100.0 \\
\hline
\end{tabular}

Signs And Symptoms:

All patients presented with symptoms with swelling, redness, pain and induration. $66 \%$ patients had blister at presentation whereas only $18.7 \%$ had skin anaesthesia and $16 \%$ had skin necrosis.

\section{Investigations}

Levels Of CRP.

Out of the 150 patients in the study, 122 patients (81\%) had CRP $>150$ whereas only 28 patients $(18.7 \%)$ had CRP $<150$

Total WBC Count:

Out of 150 cases, $42.7 \%$ of the patients had total WBC counts in the range of 15000 to $25000 \mathrm{cc} / \mathrm{m}^{3}$ whereas only $36 \%$ had total $\mathrm{WBC}$ counts $>25000 \mathrm{cc} / \mathrm{m}^{3}$ and $21.3 \%$ had $<15000 \mathrm{cc} / \mathrm{m}^{3}$.
Hemoglobin Levels:

Out of 150 cases, $56 \%$ of the total patients had hemoglobin levels less than $1 \mathrm{lg} / \mathrm{dl}$ whereas 39.3 had hemoglobin levels in the range of 11 to $13.5 \mathrm{~g} / \mathrm{dl}$.

Distribution Of Sodium:

Out of 150 cases, $81.3 \%$ presented with hyponatremia. Remaining $18.7 \%$ patients were normal.

\section{Serum Creatinine:}

Out of 150 cases, $47.3 \%$ patients had serum creatinine $>1.4$ and $52.7 \%$ had $<=1.4$.

Random Blood Sugar (RBS):

Out of 150 cases, $54.7 \%$ had a random blood sugar $>$ $180 \mathrm{mg} / \mathrm{dl}$ and remaining $45.3 \%$ were $<180 \mathrm{~m} / \mathrm{dl}$.

Table 3: LRINEC Scoring System For Necrotizing Fasciitis

\begin{tabular}{|l|l|l|}
\hline LRINEC score & No. of patients & $\%$ \\
\hline$<6.0$ & 19 & 12.7 \\
\hline$>6.0$ & 131 & 87.3 \\
\hline Total & 150 & 100.0 \\
\hline
\end{tabular}

$>6$ PPV (Positive predictive value)

In our study $87.3 \%$ of the patients had a LRINEC score $>6$.

\section{Histopathology:}

Histopathology was positive in $92 \%$ of the patients, remaining $8 \%$ were negative.

Pus Culture:

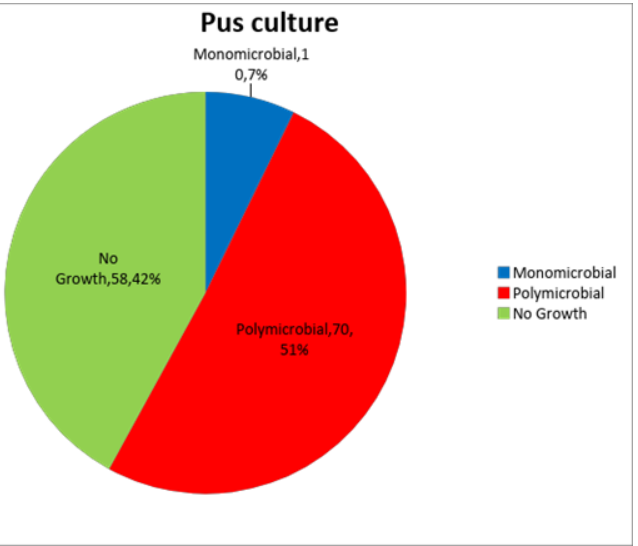

Figure 1-Pus Culture

In our series, out of the total monomicrobial pus cultures, $80 \%$ had grown Staphylococcus aureus and $20 \%$ had Streptococcus pyogenes. All the Streptococcus pyogenes containing cultures were sensitive to both Piperacillin Tazobactum and Clindamycin.

In our series where the cultures had grown more than one organism, most common organism was acinetobactor followed by E. coli. Out of the total patients who had grown E. coli, $27 \%$ of the patients were ESBL which was sensitive only to Meropenem and Imepenem.

Table 4: Correlation Of LRINEC With Histopathology Findings: Diagnostic Role Of LRINEC

\begin{tabular}{|l|l|l|l|l|l|l|}
\hline & $\begin{array}{l}\text { True } \\
\text { Positive }\end{array}$ & $\begin{array}{l}\text { False } \\
\text { Positive }\end{array}$ & $\begin{array}{l}\text { False } \\
\text { Negative }\end{array}$ & $\begin{array}{l}\text { True } \\
\text { Negative }\end{array}$ & Total & P value \\
\hline $\begin{array}{l}\text { Observ } \\
\text { ation }\end{array}$ & 125 & 6 & 13 & 6 & 150 & $\begin{array}{l}<0.001 \\
* *\end{array}$ \\
\hline & $\begin{array}{l}\text { Sensitiv } \\
\text { ity }\end{array}$ & $\begin{array}{l}\text { Specific } \\
\text { ity }\end{array}$ & PPV & NPV & $\begin{array}{l}\text { Accur } \\
\text { acy }\end{array}$ & Kappa \\
\hline $\begin{array}{l}\text { Evaluat } \\
\text { ion (\%) }\end{array}$ & 90.58 & 50.00 & 95.42 & 31.58 & 87.33 & 0.321 \\
\hline
\end{tabular}


DISCUSSION

The mean age group was $52.84 \pm 11.32$ years in the present study, it was 57.8 in L.D.Faucher.et.al ${ }^{2}$ study. In our study, $75 \%$ of the patients were males whereas it was $51 \%$ and $75 \%$ in studies conducted by L.D.Faucher.et.al ${ }^{2}$ and Rekha.et.al ${ }^{3}$ respectively. In our series, $55.3 \%$ were diabetic, $52.7 \%$ were hypertensive, $30 \%$ had chronic kidney disease and $1 \%$ had peripheral vascular disease. In the study by Rekha.et.al 73\% patients were diabetic, $13.3 \%$ had chronic kidney disease and $6.6 \%$ had peripheral vascular disease whereas in the L.D. Faucher ${ }^{2}$ series $37 \%$ had diabetes.

In our study, the most commonly involved site was extremities (upper and lower limbs) in $89.3 \%$ of the patients followed by Fournier's gangrene in $10 \%$ and abdomen in $0.7 \%$. In L.D.Faucher.et.al ${ }^{2}$, extremity involvement was seen in $51 \%$ followed by abdominal wall in $21 \%$.

In our series $36.2 \%$ of the patients had polymicrobial growth on pus culture followed by $34.7 \%$ had no growth and $28.9 \%$ had monomicrobial growth. Whereas $28 \%$ and $29 \%$ had polymicrobial growth in L.D.Faucher et.al ${ }^{2}$ series and Rekha et.al ${ }^{3}$ series respectively. So, the polymicrobial pattern in our series is comparable to the series being published.

While the average number of of polymicrobial organisms grown in our series was 2. Acinetobacter and E.coli was the common organism cultured in our series. In Taiwanese studies, 20 to $38 \%$ of patients had polymicrobial disease and 49 to $68 \%$ had monomicrobial disease ${ }^{4,5}$. Monobacterial infection was most commonly due to Streptococcus pyogenes $(25 \% \text { of cases })^{6}$. On the contrary, US studies have shown that 71 to $75 \%$ of tissue culture isolates yielded mixed aerobic and anaerobic bacteria.

In our series, the morality rate was $10 \%$ as compared to $12 \%$ and $46.67 \%$ in L.D.Faucher et.al ${ }^{2}$ and Rekha et.al ${ }^{3}$ respectively.

In our study, out of the total 150 patients, 138 patients (90\%) were proved histologically positive for necrotizing fasciitis. Out of the above 138 patients, 125 (90\%) of them had a LRINEC score of more than 6 and it was statistically significant (P value $<0.001$ ). In our study the positive predictive value of LRINEC score when it was $>6$ was $95.5 \%$ which was comparable to the $92 \%$ in original study done by Wong.et.al. The negative predictive value of LRINEC in our series was $31.58 \%$ as compared to $96 \%$ in study by Wong.et.al ${ }^{4}$. The sensitivity and specificity of LRINEC score for our series were $90.58 \%$ and 50 $\%$ which the usefulness LRINEC in reliably distinguishing necrotizing fasciitis from other soft tissue infections.

\section{CONCLUSION}

In patients with severe soft tissue infections, LRINEC scoring based on laboratory parameters is an easy and reliable diagnostic tool to diagnose Necrotizing fasciitis accurately.

\section{REFERENCES}

1. Wong CH, Khin LW, Heng KS, Tan KC, Low CO. The LRINEC (Laboratory Risk Indicator for Necrotizing Fasciitis) score: a tool for distinguishing necrotizing fasciitis from other soft tissue infections. Critical care medicine. $2004 \mathrm{Jul}$ 1;32(7):1535-41.

2. Faucher LD, Morris SE, Edelman LS, Saffle JR. Burn center management of necrotizing soft-tissue surgical infections in unburned patients. The American Journal of Surgery. 2001 Dec 1;182(6):563-9.

3. Rekha A, Ravi A. A retrospective study of necrotising fasciitis. The international journal of lower extremity wounds. 2003 Mar;2(1):46-9.

4. Lee Y, Lin J, Wang N, Peng M, Chang F. Necrotizing fasciitis in a medical center in northern Taiwan: emergence of methicillin-resistant Staphylococcus aureus in the community. JOURNAL OF MICROBIOLOGY IMMUNOLOGY AND INFECTION. 2007 Aug:40(4):335-41.

5. Brook I. Aerobic and anaerobic microbiology of necrotizing fasciitis in children. Pediatric dermatology. 1996 Jul;13(4):281-4.

6. Korhan T, Neslihan C, Atahan C, Hakan Y, Cemalettin E, Irfan B, Halit O, Recep G. Idiopathic necrotizing fasciitis: risk factors and strategies for management. The American Surgeon. 2005 Jan 1;71(4):315-20. 